This item was submitted to Loughborough's Research Repository by the author.

Items in Figshare are protected by copyright, with all rights reserved, unless otherwise indicated.

\title{
Saving liberal peacebuilding from itself
}

PLEASE CITE THE PUBLISHED VERSION

http://dx.doi.org/10.1080/10402659.2012.704328

PUBLISHER

(C) Taylor \& Francis Group, LLC

VERSION

AM (Accepted Manuscript)

LICENCE

CC BY-NC-ND 4.0

REPOSITORY RECORD

Roberts, David. 2019. "Saving Liberal Peacebuilding from Itself”. figshare. https://hdl.handle.net/2134/15360. 
This item was submitted to Loughborough's Institutional Repository (https://dspace.lboro.ac.uk/) by the author and is made available under the following Creative Commons Licence conditions.

\section{creative
commons}

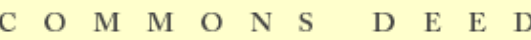

Attribution-NonCommercial-NoDerivs 2.5

You are free:

- to copy, distribute, display, and perform the work

Under the following conditions:

Attribution. You must attribute the work in the manner specified b the author or licensor.

Noncommercial. You may not use this work for commercial purposes.

No Derivative Works. You may not alter, transform, or build upon this work.

- For any reuse or distribution, you must make clear to others the license terms of this work.

- Any of these conditions can be waived if you get permission from the copyright holder.

Your fair use and other rights are in no way affected by the above.

This is a human-readable summary of the Leqal Code (the full license).

\section{Disclaimer 만}

For the full text of this licence, please go to: http://creativecommons.org/licenses/by-nc-nd/2.5/ 


\section{Peace Review}

'The evangelist was preaching... very much in earnest, and he meant well, but... what did he know... with his smooth black coat and... his belly full, and money in his pocket? - and lecturing men who were struggling for their lives... These men were out of touch with the life they discussed [and] they were unfit to solve its problems... They were trying to save their souls - and who but a fool could fail to see that all that was the matter with their souls was that they had not been able to get a decent existence for their bodies?'

Upton Sinclair, The Jungle (1906, reprinted 1985): 274.

Dr. David Roberts is Senior Lecturer in Peace and Conflict Studies at the University of Ulster. He has written four books on social justice, the most recent of which was a critique of Liberal peacebuilding, as well as more than 40 peer-reviewed articles. 


\section{Saving Liberal Peacebuilding from Itself}

\section{Introduction}

Peacebuilding is the new black. It's one of the biggest 'things' in global, international security; the palliative to the greatest threats to the North. Whether that threat comes from 'failed', 'fragile' or 'failing' states, countries on the 'periphery', Afghanistan, Iraq, Somalia, the solution is to suspend the fighting long enough to insert peacebuilders who will convert those places into law-abiding democracies that interact peacefully internationally and do not abuse their own people. Peacebuilding is the means of achieving the Liberal peace; sanctioned intervention to force change peacefully on hundreds of millions of people. The formula is simple, and the process formulaic, applied universally everywhere peacebuilding goes, from Cambodia through Nepal and Sudan to Kuwait, Liberia and Sierra Leone. Unfortunately, it doesn't do what it says it does on the tin, but smoke, mirrors, hubris and myth maintain the illusion that it does.

According to some sources, in nearly half of all interventions Liberal peacebuilding fails within 5 years, and there is little evidence of democratic practice beyond elections and truth commissions, especially in the institutions of state and leadership. Violence too often returns after peacebuilders leave, and elites routinely disguise traditional, neopatrimonial behaviour behind a patina of Liberal rhetoric and fancy nameplates on new offices. Yet, international peacebuilding policy has not changed to accommodate this rather dismal record. Whilst increasingly its advocates recognise that all is not well with the State, the solution proffered remains technical in nature: training constabulary not to abuse their power, building Upper and Lower Houses of Parliament and courts in metropolitan centres, privileging narrow, particular rights, and holding elections to manage a peaceful transfer of power in place of the war that was fought over the right to political authority.

Critics contend that these methods constitute a technical fix for social, political and economic problems that go only a limited way to creating peace. Liberal strategy, they argue, ignores the profoundly political nature of peace and substitutes bureaucratic, technical reform when the real problem is the relevance and legitimacy of the peacebuilding project for those in whose name peace is made. From this perspective, Liberal peacebuilding suffers from a legitimacy lacuna: it provides the kind of peace it believes people should have, rather than the kind of peace people might seek themselves - if their 'stakeholder' status meant something more than participation in someone else's idea of peacebuilding. Liberal peace is, then, a limited peace for a limited minority. Liberal peacebuilding advances, lionizes and secures States; it excludes, relegates and abandons societies. By this I mean that peacebuilding attempts to reproduce the Western State and legitimates that reproduction through the rhetoric of selective, particularist human rights. It then protects the State it has formed thus by prioritizing Security Sector Reform (SSR) - retrained and 'restrained' constabulary and armed forces. In this exclusive process of privileging the State, Liberal 
peacebuilding relegates social participation in the planning of peace and abandons very poor societies to the vagaries of the market, whilst the rule of law criminalizes the means of subsistence by which millions make their livings. This isn't just unfair, unbalanced and unreasonable. The consequence of fostering neglect, abandonment and thence resent through such social alienation reproduces the instability that justified intervention in the first place and, with it, more State securitization, aggravating a vicious cycle that defeats the very objective of peacebuilding missions. This is a self-fulfilling prophecy, whereby emphasizing the security of the State far above the securing of society demands further securitization of the State to protect it from the consequences of not securing society.

It must come as small surprise, then, that it is not widely adopted, adhered to and respected in postconflict spaces. Elites maul new institutions and older polities to ensure changes do not disadvantage them whilst their opponents are forced by their relative impotence in most cases to neglect or suspend democratic principles as well. There is little that will change such elite behaviour because Liberal reform is tasked with removing the conventional means of their empowerment. In the capitals, the result is hybridity: a mix of the old and the new, functioning simultaneously, interwoven, overlapping, but with the hegemony of the old masked by the rhetoric and nomenclature of the new. The patinas of democracy to be found in new buildings full of laptops connected to expensive generators for which there is little fuel conceal the extent to which neopatrimony, or corruption, or everyday life (depending on who you are) persist at all levels in most postconflict spaces.

Beyond elite power, amongst masses of very poor people who populate capital cities and in undernourished rural hinterlands, people participate willingly in elections but enjoy few of the imagined benefits. This is because it only includes them in a distant, technical sense in someone else's project; a process in stark contrast with the Liberal rhetoric of 'engagement' and 'participation', and in marked contrast with the reciprocating bonds that tie society and polity to the social contract upon which stability in the OECD states rests. In the end, Liberal peacebuilding is blind to its own illiberal character and its undemocratic exclusion of local people from determining their own fate and autonomy. It looks like Liberal peace or no peace but, as a well-known writer Claude Ake once declared, 'democratization is not something that one people does for another. People must do it for themselves or it does not happen'.

Herein lays the problem - and perhaps a solution as well. Local people do not direct the nature of the peace built in peacebuilding; they are excluded from its design, a process commandeered instead by national elites and international policy makers; what Oliver Richmond calls the 'transnational peacebuilding class'. Postconflict populations are not asked what their priorities for peace are. The situations of extreme privation, ruined infrastructure, and impoverished, land-mined societies characteristic of postconflict spaces are not the objects of the institutions advanced in Liberal peacebuilding. Such conditions are experientially tangential to the 'transnational peacebuilding class' that shapes peace; apart from some of the elites that fought in civil wars, most of those who design peace have never experienced for any length of time the privations heaped upon vulnerabilities that characterise most postconflict spaces. In focusing on narrow elite politics and institutional development in urban centres, western assumptions about what peace should look like, to whom, and when, ignore and neglect the people the institutions they build are implied to serve. How can peaceable reciprocal relations between state and society be developed, if the institutions 
of state offer little of relevance to the mass of society? International peacebuilders sustain Liberal edifices but not populations; why, then, would we expect such populations to legitimate, support and respect the new institutions of state if they don't serve pressing need?

\section{An alternative?}

If the problem is a lack of relevance and legitimacy, and the requirement is a stable mutual bond between state and society - the social contract at the heart of Liberal theory and experience - what is the solution? We have noted that orthodox thinking urges more of the same done slightly differently, whilst critics argue for a 'post-liberal' peace but advance little concrete in terms of policy. Is there a place in-between? I suggest there is: briefly, a popular peace designed by local societies, furnished externally by international society, and mobilised internally through formal and informal institutions. This constellation of forces might mobilise, peaceably, what people say they want peacebuilders to provide. The essence of such a proposition revolves around 'the everyday', a notion gaining increasing currency beyond the canons of mainstream security and international relations orthodoxy. The following section elaborates the 'everyday' to identify and illustrate the focal point around which an alternative peacebuilding, discussed later, might gravitate.

The 'everyday' refers to the myriad socially-sanctioned ways in which, to secure their being, people outsmart their environmental limitations and manage the gaps between constraints and aspirations in the face of inadequate, disinterested and incompetent authority and power. It refers to the ways people make their lives the best they can, manipulating with whatever tools and tactics at their disposal, the surrounding natural, social, economic and political structures, local and global, that empower or constrain their lives in the vandalized environment of post-conflict spaces. 'The everyday' is the way in which people manage the contingencies and opportunities they face when the state abuses them, serves them inadequately, or is null (where the State is considered neither a useful or problematic body). It is how people mobilise themselves when the state is absent from people's lives, perhaps because they live beyond its disciplinary reach, or when the state is the agent of violence against them, or when the state is active but ignores them, or is simply irrelevant to their lives, people mobilise themselves, normally in teams from the small to the large, to achieve what they need to. 'The everyday' is concerned with matters that secure the individual from routine, day-to-day contingencies unfamiliar to most international policymakers in the field of peacebuilding. It is the routines and reactions of unregulated ordinary life to the world around those lives and what those conditions necessitate of people to survive and prosper within the confines of the things they cannot change. It is the broad range of social behaviours sanctioned by local conditions and needs and the local, formal and informal, institutions that deliver, poorly or well, such provision. 'Everyday life' is immanent, imminent, ingrained and legitimated as a routine for populations in very poor and post-conflict spaces. It finds expression in informal activities from selling out-of-date aspirins outside refugee camps to the police fining motorists for going the right way down a one-way street, and survival mechanisms, from children taking food from people in outdoor restaurants to scavenging on rubbish tips. It is the routines of life that empower people to manage their existences to the best of their abilities without reference to formal regulation by the state. This is quite routinely the state of people's worlds in postconflict spaces; it reveals how and to what they allocate their resources, time and priorities, and it could provide a focus for postconflict peacebuilding that would make an intervention sufficiently relevant to heterogeneous populations that they would accept the terms and conditions attached: of the right of the state to rule peacefully. It is the terms and conditions by which the local accepts the rule of the national and the global. 
This fundamental equation is uncontested in genuinely Liberal societies; there is no reason it should not apply in postconflict peacebuilding. Engaging people around their priorities would render peacebuilding more genuinely participatory, democratic and Liberal, and perhaps help mend the battered reputation surrounding all manner of international, Liberal interventions. How, then, might international peacebuilding do this?

First, 'the everyday' can act as a focal point for the organization and mobilization of effective state and entrepreneurial delivery of public needs. It is a guide to the areas of private life that the sentient state can serve and thereby legitimate itself. Second, mobilizing state provision around peaceful, popular preferences identified with democratic instruments attuned to the variety of popular needs could make peacebuilding more responsive, participatory and emancipatory. In listening to and hearing diverse groups within a population, the state and its global patrons honour the will of the people and liberate liberal peacekeeping from the confines of its discourse and nomenclature, and the frailties of the peace it privileges. The outcome of acknowledging, hearing and responding to everyday lives is 'popular peace'. It is more than just basic needs provision or adherence to someone's particularist hierarchy of human rights. It is the democratization of peacebuilding by rendering it genuinely participatory, such that the popular will of society determines the nature of the peace to be built, whatever that might be, as long as it peacefully reflects the electorate's will.

\section{The Liberal and the Everyday}

Although to-date, Liberalism has had little to do with the 'everyday', this is not to suggest the two are exclusive. They are not. Liberalism and liberal peacebuilding involve a host of values and objectives that mesh well with 'the everyday' and with other peacebuilding preferences. A revised expression of Liberalism fostering genuinely participatory and inclusive legitimacy, democracy and human rights for political development could be directed towards the more pressing concerns and priorities of 'the everyday'. The new formula is not complex. In straightforward terms, local priorities are served by national institutions nourished by international bodies; balancing the equation, and in return, local actors begin to accept national rule of law reflecting wider global norms. This isn't so radically different from how it is addressed currently. What differs is not process but emphasis. Global governance institutions such as the World Health Organization (WHO) and World Bank could nourish core Liberal rights underpinning everyday priorities through supporting state institutions such as a National Health Service, vital public utilities or nation-wide schooling. These could be monitored and conditioned through various disciplinary mechanisms such as international NGOs (Physicians for Human Rights, Transparency International, for example) and lending regimes (International Monetary Fund, regional aid agencies).

The institutions of global governance are essential to achieving this objective; and they may also act in disciplinary fashion to ensure donors aren't taken for a ride. Liberal 'Good governance' is presently funded in accordance with global governance values and audited, rewarded and/or punished for meeting various international expectations and norms of provision. The same mechanism could apply here to new state institutions whose priorities focus on popular needs. There are various ways this might be achieved. Rewards could be offered for achieving objectives evaluated by local people using, for example, Most Significant Change (MSC) indicators (as used by international development agencies since early experiments in Bangladesh in 1996). Another way might be to tie international funding of elite institution- 
building in metropolitan centres to the successful support of everyday life, locally negotiated. Membership of important global covenants that confer international legitimacy and inter-state status might also be tied to encouraging elites to broaden their remit to formalize and institutionalize care for vulnerable populations. In other words, in addition to privileging wider peace outside the capitals, global governance bodies concerned with traditional institution-building could use their disciplinary and punitive powers to condition elite politics towards the nourishment of everyday life. This would respond not just to local needs and enhance peacebuilding, but would also confront the 'unbecoming' nature of Liberalism reflected in its disdain for basic human rights in developing countries, whilst lionizing such righs in the West. In this transversal, or horizontal popular peace (contrasting with the vertical, elite version), the successful execution of practices aimed at managing population contingencies may confer legitimacy on the institutions that provide for the population. Whether those institutions are rural or metropolitan, informal or formal, or a mixture of all, if they serve the needs of substantial population sectors, as opposed to a narrow elite, their relevance will likely render them legitimate, and they may be empowered by external support and moderated and disciplined through conditionality if violence emerges. But how are these needs to be identified and communicated democratically?

There are innumerable mechanisms in most societies that provide forums for social debate. Community Based and Province Based Organisations (CBOs and PBOs), led by elders, chiefs or other respected luminaries could hold area meetings where different groups express their priorities. Not everyone will be heard all the time; nor are they in mature democracies. But it would be a substantial leap forward compared to the amount of listening that happens under Liberal peacebuilding. The sense of participation would be enhanced meaningfully and more durably, meaning that it would be ongoing throughout the whole course of an electoral cycle, rather than being restricted to a one-shot game played only when national elections take place. The results could be transmitted via digital bulletin boards. Communities could be equipped with laptops, generators and fuel (hundreds of groups in metropolitan centres are, in the course of routine peacebuilding interventions). They could be wirelessly networked to Internet Service Providers (ISPs) using $3 \mathrm{G}$ technologies to connect the Internet to people through mobile phone networks upgraded with amplifiers and boosters for regional reach. Chin Chin Slum Town, in Freetown, Sierra Leone, although flooded 5 times a year, had in 2009 at least 5 ancient PCs powered by generators and car batteries, and was connected to a very slow speed modem for web work. If there is no electricity in one area, needs can be communicated by motos (motorcycle taxis) or other locally-accessible communications carrying pieces of paper with lists on them. Liberal peacebuilding perpetually underestimates local capacity; much can be done indigenously without romanticizing indigenous ways. Short version: connect the local to the global through the national and subnational.

This, then, is a sketch of a revised approach to peacebuilding that confronts asymmetry in the existing power dynamic, allows Liberalism to reclaim its virtue and serves the people in whose name peace is built. For popular peace to be most effective, everyday life and neoliberal exceptionalism need to renegotiate each other's terms. The two are not necessarily mutually exclusive. Such a popular peace is particular to context and messy in make-up, rather than formulaic, reactive rather than rigid, and better suited to spontaneous contingency, circumstance and complexity than the rehearsed rhetoric and ready Rubicon of neoliberal universalism. There is nothing to say this cannot happen, nor that it would be any worse than the existing process. 


\section{Conclusion}

Popular peace is more likely to be considered locally legitimate than the prevailing, failing version. Legitimacy is essential to a social contract, but it works both ways. A rebalancing of emphasis between the local and the global is apt. This marks a small shift in emphasis towards broad provision for a post-metropolitan majority but does not compromise key Liberal normative commitments to elite institutionalism and traditional Liberal values. A fusion of global and local in greater balance, accepting the concomitant hybridity of formal and informal social, political and economic institutions and practices accommodates the inevitable whilst pluralizing the possible. Instead of the requirements of global governance determining institutional preferences serving a minority and defaulting on local legitimacy, the multiple requirements of a diverse postconflict society, if met by appropriate and relevant institutions, will more likely engender the local legitimacy presently eluding orthodox peacebuilding. Global intervention moderated by local demand and composed of 'just enough' global governance regulated by its own values, including the right to life (for example) could support both formal and informal institutions aimed at basic needs provision. It could grow state institutions common to the global North, like national healthcare and education, whilst sustaining the organs it traditionally privileges, but not to the exclusion of life-saving biopolitics. Ultimately, peace of this kind could be 'emancipatory' not just for people in postconflict spaces, but also for the Liberal project, morally distressed and devalued by the distance between what it practices and what it preaches.

Recommended Readings:

\section{- Books}

o Richmond, Oliver. 2011. A Post-Liberal Peace: The Infrapolitics of Peacebuilding. London: Routledge

\section{- Articles}

o $\quad$ Roberts, David. 2011. "Postconflict Peacebuilding, Liberal Irrelevance and the Locus of Legitimacy." International Peacekeeping 18(2), pp.410-424 